Article

\title{
Polymerizable Ionic Liquid Crystals Comprising Polyoxometalate Clusters toward Inorganic-Organic Hybrid Solid Electrolytes
}

\author{
Takeru Ito ${ }^{1, *}$, Saki Otobe ${ }^{1}$, Tatsuma Oda ${ }^{2}$, Tatsuhiro Kojima ${ }^{3,4}$, Seiji Ono ${ }^{2}$, \\ Masayuki Watanabe ${ }^{2}$, Yoshiki Kiyota ${ }^{1}$, Toshiyuki Misawa ${ }^{1}$, Shinichi Koguchi ${ }^{1}$, \\ Masashi Higuchi ${ }^{2}$, Masaki Kawano ${ }^{3,5}$ and Yu Nagase ${ }^{2, *}$ \\ 1 Department of Chemistry, School of Science, Tokai University, 4-1-1 Kitakaname, \\ Hiratsuka 259-1292, Japan; sob0406qwer@gmail.com (S.O.); y-kiyota@rigaku.co.jp (Y.K.); \\ t.misawa3303@gmail.com (T.M.); koguchi@tokai-u.jp (S.K.) \\ 2 Department of Applied Chemistry, School of Engineering, Tokai University, Hiratsuka, \\ Kanagawa 259-1292, Japan; tatsuma.oda@gmail.com (T.O.); 6bajm016@mail.u-tokai.ac.jp (S.O.); \\ baseball789643@gmail.com (M.W.); mhig@tokai-u.jp (M.H.) \\ 3 Division of Advanced Materials Science, Pohang University of Science and Technology (POSTECH), \\ Pohang 790-784, Korea; kojimat15@chem.sci.osaka-u.ac.jp (T.K.); mkawano@chem.titech.ac.jp (M.K.) \\ 4 Department of Chemistry, Graduate School of Science, Osaka University, Toyonaka, Osaka 560-0043, Japan \\ 5 Department of Chemistry, School of Science, Tokyo Institute of Technology, 2-12-1 Ookayama, Meguro-ku, \\ Tokyo 152-8550, Japan \\ * Correspondence: takeito@keyaki.cc.u-tokai.ac.jp (T.I.); yunagase@tokai-u.jp (Y.N.); \\ Tel.: +81-463-58-1211 (ext. 3737) (T.I.); +81-463-58-1211 (ext. 4179) (Y.N.)
}

Academic Editor: Changsik Song

Received: 15 June 2017; Accepted: 17 July 2017; Published: 20 July 2017

\begin{abstract}
Solid electrolytes are crucial materials for lithium-ion or fuel-cell battery technology due to their structural stability and easiness for handling. Emergence of high conductivity in solid electrolytes requires precise control of the composition and structure. A promising strategy toward highly-conductive solid electrolytes is employing a thermally-stable inorganic component and a structurally-flexible organic moiety to construct inorganic-organic hybrid materials. Ionic liquids as the organic component will be advantageous for the emergence of high conductivity, and polyoxometalate, such as heteropolyacids, are well-known as inorganic proton conductors. Here, newly-designed ionic liquid imidazolium cations, having a polymerizable methacryl group (denoted as MAImC $\left.\mathrm{C}_{1}\right)$, were successfully hybridized with heteropolyanions of $\left[\mathrm{PW}_{12} \mathrm{O}_{40}\right]^{3-}\left(\mathrm{PW}_{12}\right)$ to form inorganic-organic hybrid monomers of $\mathrm{MAImC}_{1}-\mathrm{PW}_{12}$. The synthetic procedure of $\mathrm{MAImC}_{1}-\mathrm{PW}_{12}$ was a simple ion-exchange reaction, being generally applicable to several polyoxometalates, in principle. MAImC $\mathrm{C}_{1}-\mathrm{PW}_{12}$ was obtained as single crystals, and its molecular and crystal structures were clearly revealed. Additionally, the hybrid monomer of $M A \mathrm{ImC}_{1}-\mathrm{PW}_{12}$ was polymerized by a radical polymerization using AIBN as an initiator. Some of the resulting inorganic-organic hybrid polymers exhibited conductivity of $10^{-4} \mathrm{~S} \cdot \mathrm{cm}^{-1}$ order under humidified conditions at $313 \mathrm{~K}$.
\end{abstract}

Keywords: inorganic-organic hybrid; polymer; ionic liquid; polyoxometalate; conductivity

\section{Introduction}

The development of highly-conductive solid electrolytes is crucial for innovative battery technology, such as lithium-ion and fuel-cell batteries [1-4], which are now being applied to power sources of motor vehicles working at intermediate temperature of 373 to $573 \mathrm{~K}$. However, they demand highly-conductive solid electrolyte to overcome some drawbacks when used at 
intermediate temperatures. In most lithium-ion batteries, flammable organic-liquid electrolytes are used, which should be substituted for safer solid electrolytes. Polymer electrolyte membrane fuel cells (PEMFC) use proton-conducting fluorocarbon polymers (Nafion) exhibiting high conductivity only under humidified conditions below $373 \mathrm{~K}$, and highly-conductive solid electrolytes working at intermediate temperatures without humidity are demanded. However, present solid electrolytes, to date, are insufficient in their conductivities.

A promising option toward highly-conductive solid electrolytes is to employ a thermally-stable inorganic component and a structurally-flexible organic moiety to construct inorganic-organic hybrid conductors [5,6]. Ionic liquids exhibit characteristic conductive properties [7-9], and enable the construction of conductive materials [10-13].

As for the inorganic moiety, the vast series of polyoxometalate (POM) inorganic clusters have unique redox properties [14-19]. Heteropolyacids, one category of POMs, are well known as highly proton-conductive materials [20-22]. However, the application of heteropolyacids is limited due to their hygroscopicity. Hybridization of heteropolyacids with polymers by simple combining has been reported for the emergence of anhydrous proton conductivity at intermediate temperatures [23,24], while precise control of the material's structure and composition is rather difficult. Hybrid polymers utilizing precisely-synthesized POM anions with a covalently-grafted polymerizable group have been realized [25-36], however, this kind of organically-modified POM is limited. Polymerizable organic cations have been rarely employed to construct POM hybrid polymers [37,38], and have not been hybridized with heteropolyacids.

Here, conductive inorganic-organic hybrid monomer and polymers were synthesized by using newly-designed ionic liquid imidazolium cations having a polymerizable methacryl group $\left(\left[\left\{\mathrm{CH}_{2}=\mathrm{C}\left(\mathrm{CH}_{3}\right) \mathrm{COO}\left(\mathrm{CH}_{2}\right)_{2}\right\} \mathrm{C}_{3} \mathrm{H}_{3} \mathrm{~N}_{2}\left(\mathrm{CH}_{3}\right)\right]^{+}\right.$, denoted as MAImC $\mathrm{C}_{1}$, Figure 1). MAImC $\mathrm{C}_{1}$ was successfully hybridized with heteropolyoxometalate (dodecatungstophosphate, $\left[\mathrm{PW}_{12} \mathrm{O}_{40}\right]^{3-}\left(\mathrm{PW}_{12}\right)$, Figure 1) to obtain a hybrid monomer of $\mathrm{MAImC}_{1}-\mathrm{PW}_{12}$ as single crystals. Radical polymerization of $\mathrm{MAImC}_{1}-\mathrm{PW}_{12}$ hybrid monomer enabled the syntheses of several hybrid homopolymers $\left(\mathrm{P}-\mathrm{MAImC} \mathrm{C}_{1}-\mathrm{PW}_{12}\right)$ and copolymers $\left(\mathrm{CP}-\mathrm{MAImC} \mathrm{C}_{1}-\mathrm{PW}_{12}\right)$, some of which exhibited $5.7 \times 10^{-4} \mathrm{~S} \cdot \mathrm{cm}^{-1}$ under humidified conditions at $313 \mathrm{~K}$.

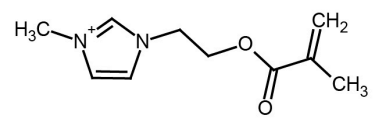

$\mathrm{MAImC}_{1}$

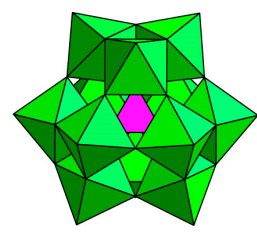

$\mathrm{PW}_{12}$

Figure 1. Molecular structure of the $\mathrm{MAImC}_{1}$ cation (left) and the dodecatungstophosphate $\left(\mathrm{PW}_{12}\right)$ anion (right).

\section{Materials and Methods}

\subsection{Materials}

All chemical reagents, except for ionic liquid imidazolium cations, were purchased from Wako Pure Chemical Industries, Ltd. (Wako) (Tokyo, Japan) and Tokyo Chemical Industry Co., Ltd. (TCI) (Tokyo, Japan). 2,2'-Azobis(isobutyronitrile) (AIBN, Wako) was purified by recrystallization from ethanol before use, and the other reagents were employed as received. MAImC $\mathrm{M}_{1}$ and $\left[\left\{\mathrm{CH}_{2}=\mathrm{C}\left(\mathrm{CH}_{3}\right) \mathrm{COO}\left(\mathrm{CH}_{2}\right)_{2}\right\} \mathrm{C}_{3} \mathrm{H}_{3} \mathrm{~N}_{2}\left(\mathrm{C}_{8} \mathrm{H}_{17}\right)\right]^{+}\left(\mathrm{MAImC}_{8}\right)$ were prepared as iodide salt $\left(\mathrm{MAImC}_{1}-\mathrm{I}\right)$ and bromide salt $\left(\mathrm{MAImC}_{8}-\mathrm{Br}\right)$, respectively, according to the procedures described below. 


\subsection{Genaral Methods for Characterization}

IR spectra (as a KBr pellet) were recorded on a Jasco FT/IR-4200ST spectrometer (JASCO Corporation, Tokyo, Japan). Powder X-ray diffraction (XRD) patterns were measured with a Rigaku MiniFlex300 diffractometer (Rigaku Corporation, Tokyo, Japan) by using $\mathrm{Cu} \mathrm{K} \alpha$ radiation $(\lambda=1.54056 \AA)$ at ambient temperature. CHN elemental analyses were performed with a PerkinElmer $2400 I I$ elemental analyzer.

Solution ${ }^{1} \mathrm{H}$ NMR spectroscopy was conducted with a Bruker AVANCE-500 NMR spectrometer (Bruker Corporation, Yokohama, Japan) (500 MHz) at room temperature. Gel permeation chromatography (GPC) was carried out to determine the number-average $\left(M_{n}\right)$ and weight-average $\left(M_{\mathrm{W}}\right)$ molecular weights with a Tosoh GPC system (Tosoh Corporation, Tokyo, Japan) equipped with four columns of TSK gels, Multipore HXL-M, and a Tosoh RI-8010 detector (Tosoh Corporation, Tokyo, Japan) with a Tosoh CCPD pump (Tosoh Corporation, Tokyo, Japan), using DMF solution containing $20 \mathrm{mM} \mathrm{LiBr}$ as an eluent at a flow rate of $1.0 \mathrm{~mL} \mathrm{~min}^{-1}$. GPC was also conducted for THF-soluble polymers with a Tosoh HLC-8320GPC (Tosoh Corporation, Tokyo, Japan) equipped with four columns of TSK gels, and a Super-Multipore HZ-H, using THF as an eluent at a flow rate of $1.0 \mathrm{~mL} \mathrm{~min}^{-1}$. Standard polystyrenes were used to calibrate the molecular weights. Differential scanning calorimetry (DSC) and thermal gravimetric analysis (TGA) were carried out on a Seiko Instruments DSC-6200 (Seiko Instruments Inc., Chiba, Japan) and TG/DTA-6200 (Seiko Instruments Inc., Chiba, Japan), respectively, at a heating rate of $10 \mathrm{~K} \cdot \mathrm{min}^{-1}$ under a nitrogen atmosphere.

Conductivity measurements were carried out by the alternating current (AC) impedance method. Pelletized powder samples sandwiched with Pt electrodes were employed. Conductivities under ambient atmosphere of relative humidity (RH) $~ 30 \%$ and fully-humidified conditions of RH $95 \%$ were measured in a frequency range from 20 to $1.0 \times 10^{6} \mathrm{~Hz}$ using an Agilent technologies 4284A (Keysight Technologies, California, USA) or a HIOKI 3532-50 inductance-capacitance-resistance (LCR) (HIOKI E.E. Corporation, Nagano, Japan) meter coupled with an Espec SH-641 (ESPEC Corporation, Osaka, Japan) bench-top type temperature and humidity chamber.

\subsection{Synthesis}

\subsubsection{Synthesis of $\mathrm{MAImC}_{1}-\mathrm{I}$}

Synthesis of 1-(2-Chloroethyl)-1H-imidazole

The solution of imidazole $2.04 \mathrm{~g}$ ( $30 \mathrm{mmol}$; TCI, purity > 98.0\%) in 1,2-dichloroethane (30 mL; TCI, purity $>99.5 \%)$ was added to tetrabutylammonium bromide $0.20 \mathrm{~g}(0.6 \mathrm{mmol})$ and $\mathrm{K}_{2} \mathrm{CO}_{3} 0.82 \mathrm{~g}$ $(6 \mathrm{mmol})$. The result mixture was stirred at $358 \mathrm{~K}$ for $5 \mathrm{~h}$. The mixture was extracted with $\mathrm{CHCl}_{3}$, and the organic layer was washed with water, dried $\left(\mathrm{MgSO}_{4}\right)$ and evaporated. The product was isolated by silica gel column chromatography to give the title compound $(1.47 \mathrm{~g}, 37 \%)$ as a colorless liquid. ${ }^{1} \mathrm{H} \mathrm{NMR}\left(500 \mathrm{MHz}, \mathrm{CDCl}_{3}\right) \delta 3.76(\mathrm{t}, J=10 \mathrm{~Hz}, 2 \mathrm{H}), 4.28(\mathrm{t}, J=10 \mathrm{~Hz}, 2 \mathrm{H}), 6.98(\mathrm{~s}, 1 \mathrm{H}), 7.10(\mathrm{~s}, 1 \mathrm{H}), 7.54$ $(\mathrm{s}, 1 \mathrm{H})$.

Synthesis of 2-(1H-Imidazol-1-yl) Ethyl Methacrylate

The solution of 1-(2-chloroethyl)-1H-imidazole $1.13 \mathrm{~g}(13.2 \mathrm{mmol})$ in THF $(25 \mathrm{~mL})$ was added to methacrylic acid $1.47 \mathrm{~g}$ (11.2 mmol; TCI, purity > 99.0\%) and $\mathrm{K}_{2} \mathrm{CO}_{3} 3.58 \mathrm{~g}(25.9 \mathrm{mmol})$. The resulting mixture was stirred at $339 \mathrm{~K}$ overnight. The mixture was extracted with $\mathrm{CHCl}_{3}$, and the organic layer was washed with water, dried $\left(\mathrm{MgSO}_{4}\right)$, and evaporated. The product was isolated by silica gel column chromatography to give $1.70 \mathrm{~g}(84 \%)$ of the title compound as a colorless liquid. ${ }^{1} \mathrm{H}$ NMR $(500 \mathrm{MHz}$, $\left.\mathrm{CDCl}_{3}\right) \delta 1.93(\mathrm{~s}, 3 \mathrm{H}), 4.25(\mathrm{t}, J=5 \mathrm{~Hz}, 3 \mathrm{H}), 4.40(\mathrm{t}, J=5 \mathrm{~Hz}, 3 \mathrm{H}), 5.61(\mathrm{~s}, 1 \mathrm{H}), 6.10(\mathrm{~s}, 1 \mathrm{H}), 6.96(\mathrm{~s}, 1 \mathrm{H})$, $7.08(\mathrm{~s}, 1 \mathrm{H}), 7.51(\mathrm{~s}, 1 \mathrm{H})$. 
Synthesis of 1-(2-(Methacryloyloxy) Ethyl)-3-Methyl-1H-Imidazol-3-ium Iodide (MAImC ${ }_{1}$-I)

The solution of 2-(1H-imidazol-1-yl) ethyl methacrylate $10 \mathrm{~g}(55.6 \mathrm{mmol})$ in $39.4 \mathrm{~g}$ (278 mmol; TCI, purity $>99.5 \%$ ) iodomethane was stirred at 333 overnight. The product was isolated by silica gel column chromatography to give $8.45 \mathrm{~g}(52 \%)$ of the title compound as a brown liquid. ${ }^{1} \mathrm{H}$ NMR $\left(500 \mathrm{MHz}, \mathrm{CDCl}_{3}\right) \delta 1.85(\mathrm{~s}, 3 \mathrm{H}), 3.86(\mathrm{~s}, 3 \mathrm{H}), 4.43(\mathrm{t}, J=5.5 \mathrm{~Hz}, 3 \mathrm{H}), 4.52(\mathrm{t}, J=5.5 \mathrm{~Hz}, 3 \mathrm{H}), 5.72(\mathrm{~s}, 1 \mathrm{H})$, $6.04(\mathrm{~s}, 1 \mathrm{H}), 7.71(\mathrm{~s}, 1 \mathrm{H}), 7.79(\mathrm{~s}, 1 \mathrm{H}), 9.15(\mathrm{~s}, 1 \mathrm{H})$.

Synthesis of 1-(2-(Methacryloyloxy) Ethyl)-3-Octyl-1H-Imidazol-3-ium Bromide (MAImC8-Br)

The solution of 2-(1H-imidazol-1-yl) ethyl methacrylate $0.61 \mathrm{~g}(3.4 \mathrm{mmol})$ in 1-bromooctane $1.15 \mathrm{~g}$ ( 6 mmol; TCI, purity $>98.0 \%$ ) was stirred at $333 \mathrm{~K}$ overnight. The product was isolated by silica gel column chromatography to give $1.00 \mathrm{~g}(80 \%)$ of the title compound as a yellow liquid. ${ }^{1} \mathrm{H}$ NMR $\left(500 \mathrm{MHz}, \mathrm{DMSO}-d_{6}\right) \delta 0.86(\mathrm{t}, J=6.91 \mathrm{~Hz}, 3 \mathrm{H}), 1.25(\mathrm{~m}, 10 \mathrm{H}), 1.77(\mathrm{~m}, 2 \mathrm{H}), 1.85(\mathrm{t}, J=1.14 \mathrm{~Hz}, 3 \mathrm{H})$. $4.19(\mathrm{t}, J=6.93 \mathrm{~Hz}, 2 \mathrm{H}), 4.48(\mathrm{~m}, 2 \mathrm{H}), 4.54(\mathrm{t}, J=4.41 \mathrm{~Hz}, 2 \mathrm{H}) .5 .72$ (quint., $J=1.61 \mathrm{~Hz}, 1 \mathrm{H}), 6.03(\mathrm{t}$, $J=1.13 \mathrm{~Hz}, 1 \mathrm{H}), 7.85(\mathrm{~m}, 2 \mathrm{H}), 9.29(\mathrm{~s}, 1 \mathrm{H})$.

\subsubsection{Synthesis of $\mathrm{MAImC}_{1}-\mathrm{PW}_{12}$ Hybrid Monomer}

Dodecatungstophosphoric acid $n$ hydrate $\left(\mathrm{H}_{3}\left[\mathrm{PW}_{12} \mathrm{O}_{40}\right] \cdot n \mathrm{H}_{2} \mathrm{O}\left(\mathrm{H}-\mathrm{PW}_{12}\right), 1.70 \mathrm{~g}(5.3 \mathrm{mmol})\right.$; Wako (Tokyo, Japan), Special Grade) was dissolved in $10 \mathrm{~mL}$ of ethanol, and slight amounts of insoluble solid that sometimes remained were filtered off. To the obtained clear colorless solution was added an ethanol solution $(5 \mathrm{~mL})$ of MAImC $_{1}-\mathrm{I}(0.50 \mathrm{~g}, 1.55 \mathrm{mmol})$ to form a colorless suspension. The suspension was filtered to result in colorless precipitate, which was washed by water and dried under ambient atmosphere to obtain the as-prepared hybrid monomer of $\mathrm{MAImC}_{1}-\mathrm{PW}_{12}(1.3 \mathrm{~g}$, yield: $57 \%$ ). Colorless block crystals of $\mathrm{MAImC}_{1}-\mathrm{PW}_{12}$ were grown from the synthetic filtrate by keeping at $279 \mathrm{~K}$. As-prepared $\mathrm{MAImC}_{1}-\mathrm{PW}_{12}$ hybrid monomer started to shrink and melt over $353 \mathrm{~K}$. Anal.: Calcd for $\mathrm{C}_{30} \mathrm{H}_{45} \mathrm{~N}_{6} \mathrm{PW}_{12} \mathrm{O}_{46}$ : C: 10.41, H: 1.31, N: 2.43\%. Found: C: 13.70, H: 1.60, N: $2.33 \%$. IR (KBr disk): $3161(\mathrm{w}), 2961(\mathrm{w}), 2926(\mathrm{w}), 1723(\mathrm{w}), 1636(\mathrm{w}), 1560(\mathrm{w}), 1455(\mathrm{w}), 1316(\mathrm{w}), 1295(\mathrm{w}), 1164(\mathrm{w})$, $1080(\mathrm{~m}), 1046(\mathrm{w}) .978(\mathrm{~s}), 896(\mathrm{~m}), 808(\mathrm{~s}), 738(\mathrm{w}), 649(\mathrm{w}), 622(\mathrm{w}), 597(\mathrm{w}), 516(\mathrm{w}) \mathrm{cm}^{-1}$.

\subsubsection{Syntheses of P-MAImC ${ }_{1}-\mathrm{PW}_{12}$ Hybrid Homopolymers}

In a $50 \mathrm{~mL}$ eggplant flask, $1.00 \mathrm{~g}(0.297 \mathrm{mmol})$ of MAImC $1-\mathrm{PW}_{12}$ and $24.4 \mathrm{mg}(0.149 \mathrm{mmol})$ of 2,2'-azobis(isobutyronitrile) (AIBN; Wako, recrystallized) were dissolved in $4.3 \mathrm{~mL}$ of DMF. After degassing the flask, it was sealed by a three-way cock, and the mixture was stirred at 353 $\mathrm{K}$ for $20 \mathrm{~h}$. Then, the reaction mixture was poured into $100 \mathrm{~mL}$ of methanol to precipitate the polymer. The obtained polymer was filtered and dried in vacuo to afford $0.852 \mathrm{~g}$ of P-MAImC $1-\mathrm{PW}_{12}$ (Yield: 85.2\%).

\subsubsection{Syntheses of CP-MAImC ${ }_{1}-\mathrm{PW}_{12} /$ BMA Hybrid Copolymers}

The radical copolymerizations were carried out for the mixtures of $\mathrm{MAImC}_{1}-\mathrm{PW}_{12}$ and butyl methacrylate (BMA; TCI (Tokyo, Japan), purity > 99.0\%) to prepare copolymers with different compositions of monomer units. The typical procedure of copolymerization is described below.

In a $50 \mathrm{~mL}$ eggplant flask, $0.536 \mathrm{~g}(0.152 \mathrm{mmol})$ of $\mathrm{MAImC}_{1}-\mathrm{PW}_{12}, 0.536 \mathrm{~g}(3.77 \mathrm{mmol})$ of BMA, and $12.7 \mathrm{mg}(0.0773 \mathrm{mmol})$ of AIBN were dissolved in $4.5 \mathrm{~mL}$ of DMF. After degassing the flask, it was sealed by a three-way cock, and the mixture was stirred at $353 \mathrm{~K}$ for $20 \mathrm{~h}$. Then, the reaction mixture was poured into $120 \mathrm{~mL}$ of methanol to precipitate the polymer. The obtained polymer was filtered and dried in vacuo to afford $0.659 \mathrm{~g}$ of CP-MAImC 1 -PW 12 /BMA (1:1) (Yield: 61.4\%). 


\subsubsection{Syntheses of CP-MAImC 1 -PW 12 /MAImC $C_{8}$ Br Hybrid Copolymers}

The similar radical copolymerizations were carried out for the mixtures of MAImC $1-\mathrm{PW}_{12}$ and $\mathrm{MAImC}_{8} \mathrm{Br}$ to prepare copolymers with different compositions. The typical procedure of copolymerization is described below.

In a $50 \mathrm{~mL}$ eggplant flask, $0.805 \mathrm{~g}(0.239 \mathrm{mmol})$ of MAImC $1-\mathrm{PW}_{12}, 0.805 \mathrm{~g}(2.16 \mathrm{mmol})$ of MAImC $_{8}-\mathrm{Br}$, and $8.0 \mathrm{mg}(0.049 \mathrm{mmol})$ of AIBN were dissolved in $6.8 \mathrm{~mL}$ of DMF. After degassing the flask, it was sealed by a three-way cock, and the mixture was stirred at $353 \mathrm{~K}$ for $20 \mathrm{~h}$. Then, the reaction mixture was poured into $150 \mathrm{~mL}$ of ethyl acetate to precipitate the polymer. The obtained polymer was filtered and dried in vacuo to afford $1.06 \mathrm{~g}$ of CP-MAImC ${ }_{1}-\mathrm{PW}_{12} / \mathrm{MAImC}_{8} \mathrm{Br}$ (1:1) (Yield: 65.8\%).

\subsection{X-ray Crystallography}

Single crystal X-ray diffraction data for hybrid monomer of MAImC $\mathrm{C}_{1}-\mathrm{PW}_{12}$ was recorded with an ADSC Q210 CCD area detector (Area Detector Systems Corporation, Poway, CA, USA) with synchrotron radiation at the 2D beamline at the Pohang Accelerator Laboratory (PAL). The diffraction images were processed by using HKL3000 (HKL Research, Inc., Charlottesville, VA, USA) [39]. Absorption correction was performed with the program PLATON [40]. The structure was solved by the direct methods using SHELXT version 2014/5 [41] and refined by the full-matrix least-squares method on $F^{2}$ using SHELXL version 2014/7 [42]. Further details of the crystal structure investigation may be obtained free of charge from the Cambridge Crystallographic Data Centre, 12 Union Road, Cambridge CB2 1EZ, UK; Fax: (+44) 1223336 033; or E-Mail: deposit@ccdc.cam.ac.uk (CCDC 1555936).

\section{Results}

\subsection{Synthesis and Structure of $M A I m C_{1}-P W_{12}$ Hybrid Monomer}

Synthesis of starting polymerizable ionic liquid of $\mathrm{MAImC}_{1}$ was obtained as iodide salt according to Scheme 1 (see the Materials and Methods section).

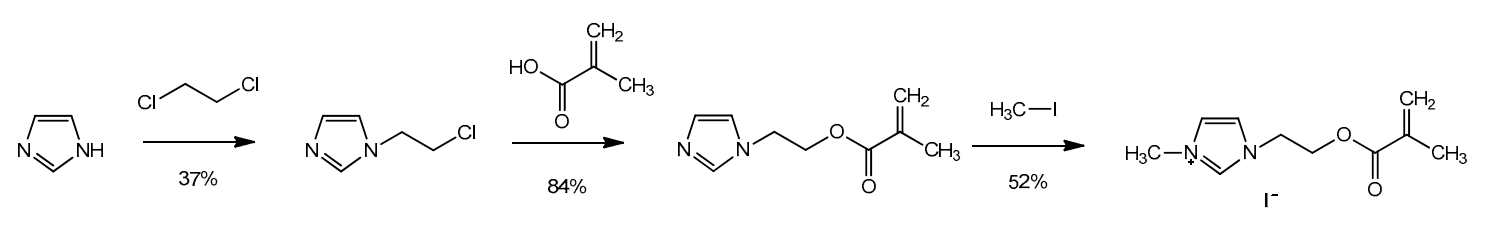

Scheme 1. Synthetic route of $\mathrm{MAImC}_{1}-\mathrm{I}$.

The colorless precipitate of the $\mathrm{MAImC}_{1}-\mathrm{PW}_{12}$ hybrid monomer was successfully obtained by a cation exchange reaction of dodecatungstophosphoric acid ( $\left.\mathrm{H}-\mathrm{PW}_{12}\right)$ by $\mathrm{MAImC}_{1}$, as reported for the syntheses of ionic liquid surfactant-polyoxometalate hybrid crystals [43-45]. As shown in Figure $2 \mathrm{a}$, IR spectrum of the MAImC $\mathrm{C}_{1}-\mathrm{PW}_{12}$ hybrid monomer exhibited characteristic peaks of dodecatungstophosphate $\left(\mathrm{PW}_{12}\right)$ anion in the range of $400-1100 \mathrm{~cm}^{-1}[17,46]$, as well as peaks derived from MAImC M $_{1}$ (methylene groups in 2800-3000 $\mathrm{cm}^{-1}$ and methacryl group in 1200-1800 $\mathrm{cm}^{-1}$ ). This indicates the successful hybridization of polymerizable $\mathrm{MAImC}_{1}$ cations and $\mathrm{PW}_{12}$ anions. The XRD pattern of the MAImC $1-\mathrm{PW}_{12}$ hybrid monomer obtained as the initial precipitate was almost the same as the pattern calculated from the results of the single crystal X-ray analysis (Figure 2b), indicating that the as-prepared precipitate and single crystals of $\mathrm{MAImC}_{1}-\mathrm{PW}_{12}$ had the same composition and structure. Differences in the peak intensity and position of the patterns may be due to the difference in the measurement temperature (powder: ambient temperature, single crystal: $100 \mathrm{~K})$. 

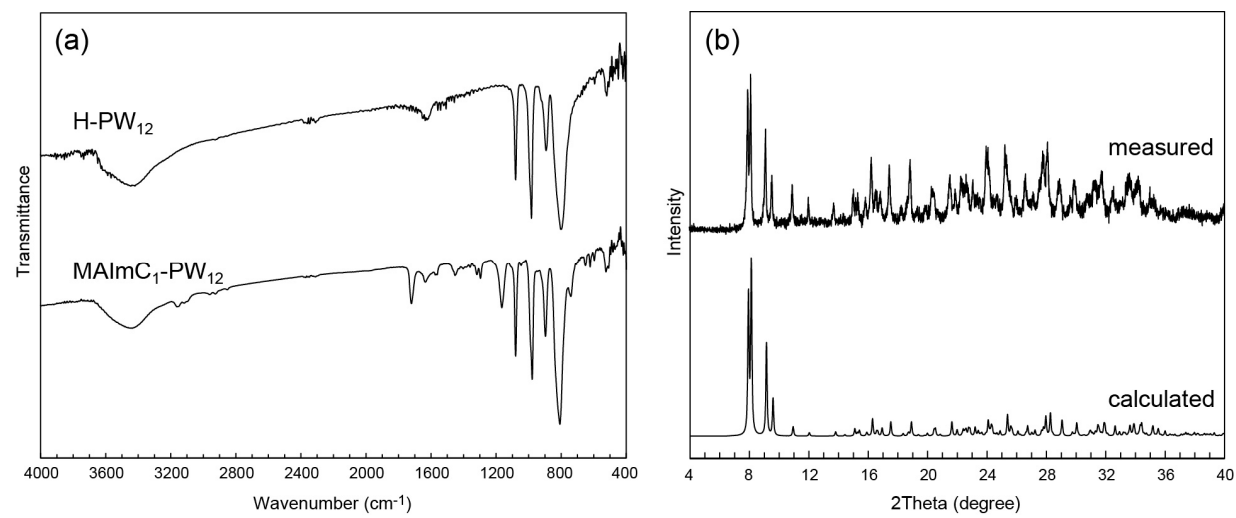

Figure 2. (a) IR spectra of $\mathrm{H}-\mathrm{PW}_{12}$ (upper) and $\mathrm{MAImC}_{1}-\mathrm{PW}_{12}$ hybrid monomers (bottom); and (b) powder X-ray diffraction patterns of the $\mathrm{MAImC}_{1}-\mathrm{PW}_{12}$ hybrid monomer measured under ambient atmosphere (upper) and calculated by using the structure obtained by single-crystal X-ray diffraction (bottom).

The molecular structure was clearly revealed by single-crystal $\mathrm{X}$-ray structure analysis (Table 1, Figure 3). The chemical formula was $\left[\left\{\mathrm{CH}_{2}=\mathrm{C}\left(\mathrm{CH}_{3}\right) \mathrm{COO}\left(\mathrm{CH}_{2}\right)_{2}\right\} \mathrm{C}_{3} \mathrm{H}_{3} \mathrm{~N}_{2}\left(\mathrm{CH}_{3}\right)\right]_{3}\left[\mathrm{PW}_{12} \mathrm{O}_{40}\right]$ $\left(\mathrm{MAImC}_{1}-\mathrm{PW}_{12}\right)$, and three protons of $\mathrm{H}-\mathrm{PW}_{12}$ were completely exchanged by three $\mathrm{MAImC}_{1}$ cations. As shown in Figure 3a, there were two crystallographically-independent $\mathrm{MAImC}_{1}$ cations, one of which was disordered near the two-fold axis with a site occupancy of 0.5 . The $\mathrm{PW}_{12}$ anion lay on the inversion center, and exhibited a common type of disorder for the Keggin anion noted previously $[47,48]$.

Table 1. Crystallographic data of the $\mathrm{MAImC}_{1}-\mathrm{PW}_{12}$ hybrid monomer.

\begin{tabular}{|c|c|}
\hline Compound & MAImC $_{1}-\mathrm{PW}_{12}$ \\
\hline Chemical formula & $\mathrm{C}_{30} \mathrm{H}_{45} \mathrm{~N}_{6} \mathrm{PW}_{12} \mathrm{O}_{46}$ \\
\hline Formula weight & 3462.87 \\
\hline Crystal system & Monoclinic \\
\hline Space group & C2/c (No. 15) \\
\hline$a(\AA)$ & $18.9467(2)$ \\
\hline$b(\AA)$ & $14.6994(2)$ \\
\hline$c(\AA)$ & $22.9023(4)$ \\
\hline$\alpha\left({ }^{\circ}\right)$ & 90.0000 \\
\hline$\beta\left({ }^{\circ}\right)$ & $103.390(1)$ \\
\hline$\gamma\left({ }^{\circ}\right)$ & 90.0000 \\
\hline$V\left(\AA^{3}\right)$ & $6205.02(15)$ \\
\hline Z & 4 \\
\hline$\varrho_{\text {calcd }}\left(\mathrm{g} \mathrm{cm}^{-3}\right)$ & 3.707 \\
\hline$T(\mathrm{~K})$ & $100(2)$ \\
\hline Wavelength $(\AA)$ & 0.70000 \\
\hline$\mu\left(\mathrm{mm}^{-1}\right)$ & 20.615 \\
\hline No. of reflections measured & 29,677 \\
\hline No. of independent reflections & 8833 \\
\hline$R_{\text {int }}$ & 0.0525 \\
\hline No. of parameters & 505 \\
\hline$R_{1}(I>2 \sigma(I))$ & 0.0641 \\
\hline$w R_{2}$ (all data) & 0.1651 \\
\hline
\end{tabular}


(a)

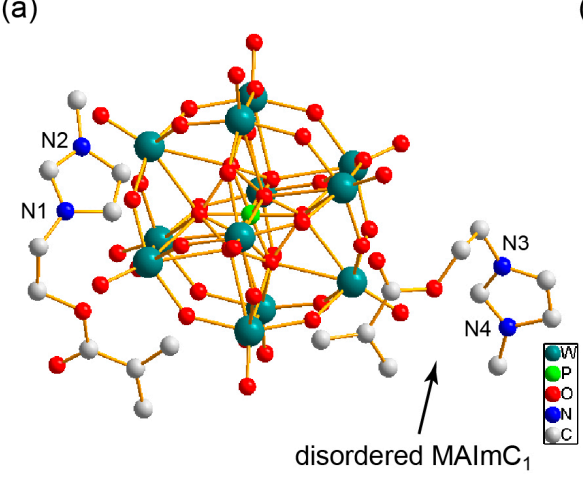

(b)

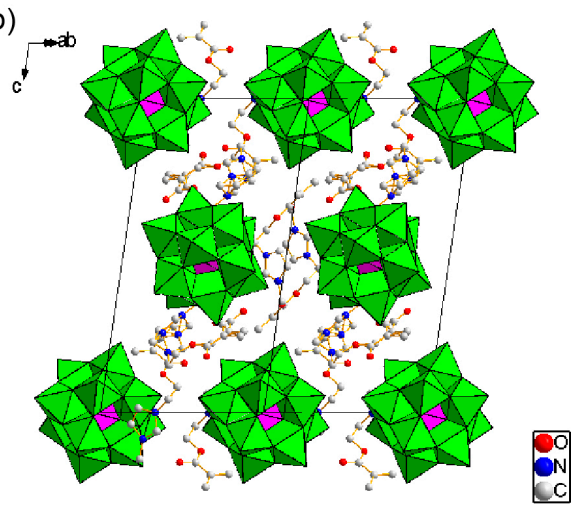

Figure 3. Crystal structure of $\mathrm{MAImC}_{1}-\mathrm{PW}_{12}$ hybrid monomer. $\mathrm{H}$ atoms are omitted for clarity: (a) asymmetric unit together with $\mathrm{PW}_{12}$ anion completed by symmetry operation $(0.5-x, 0.5-y$, $1-z)$; and (b) packing diagram along the $[-1,1,0]$ direction.

\subsection{Synthesis of $M A I m C_{1}-P W_{12}$ Hybrid Homo- and Copolymers}

The radical polymerization of the obtained MAImC $\mathrm{C}_{1}-\mathrm{PW}_{12}$ hybrid monomer and the copolymerizations with vinyl monomers, butyl methacrylate (BMA), and $\mathrm{MAImC}_{8}$ - $\mathrm{Br}$ were carried out by using AIBN as an initiator as shown in Scheme 2. The yields and the molecular weights of the obtained polymers are shown in Table $2 . \mathrm{MAImC}_{1}-\mathrm{PW}_{12}$ hybrid monomer was successfully polymerized by using about a half equivalent of AIBN against the monomer, where the homopolymer was soluble in some organic solvents and the weight-average molecular weight was 7960. The homopolymer, P-MAImC $1-\mathrm{PW}_{12}$, was soluble in DMF, DMSO, and NMP, but insoluble in methanol, chloroform, and THF. On the other hand, the copolymerization of the $\mathrm{MAImC}_{1}-\mathrm{PW}_{12}$ hybrid monomer with BMA and $\mathrm{MAImC}_{8}$-Br were conducted using a 1/50 equivalent amount of AIBN against the monomers to yield high molecular weight copolymers. The copolymers of $\mathrm{MAImC}_{1}-\mathrm{PW}_{12}$ with BMA, CP-MAImC ${ }_{1}-\mathrm{PW}_{12} / \mathrm{BMA}$, were widely soluble in chloroform, THF, DMF, and NMP, however, the copolymers of $\mathrm{MAImC}_{1}-\mathrm{PW}_{12}$ with $\mathrm{MAImC}$ - $\mathrm{Br}, \mathrm{CP}-\mathrm{MAImC} \mathrm{Im}_{1}-\mathrm{PW}_{12} / \mathrm{MAImC}_{8} \mathrm{Br}$, were only soluble in NMP. Therefore, GPC measurement of CP-MAImC ${ }_{1}-\mathrm{PW}_{12} / \mathrm{MAImC}_{8} \mathrm{Br}$ could not be conducted.

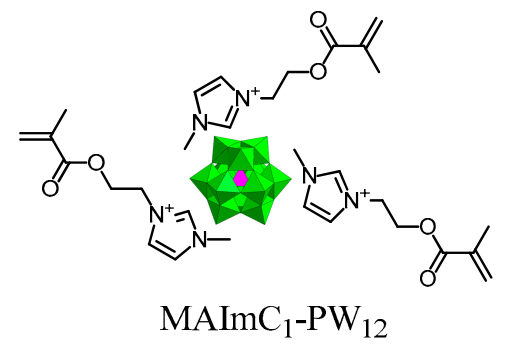

$\mathrm{MAImC}_{1}-\mathrm{PW}_{12}$

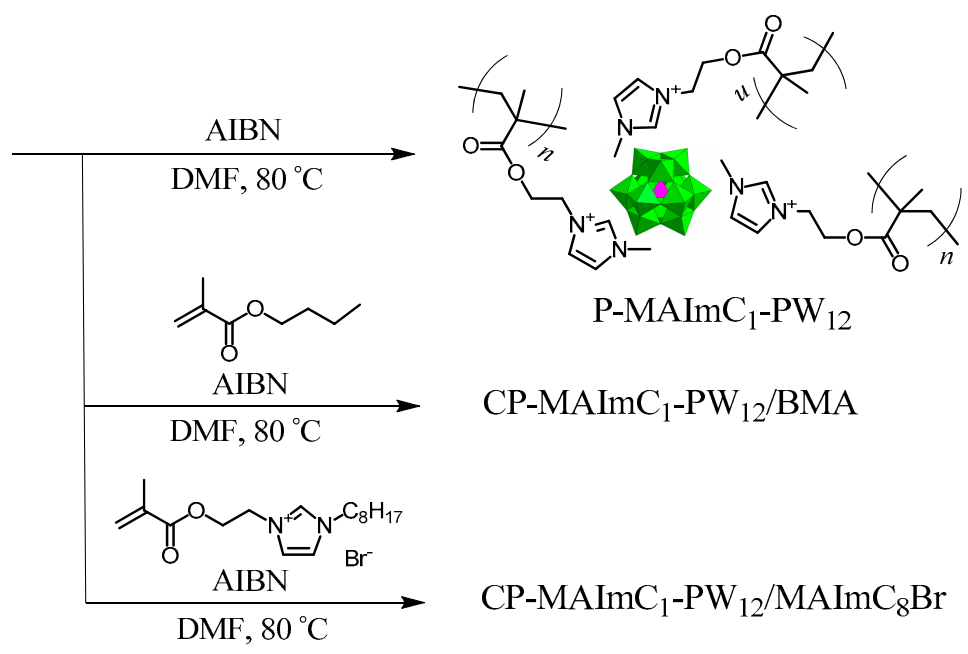

Scheme 2. Synthesis of MAImC $\mathrm{C}_{1}-\mathrm{PW}_{12}$ hybrid homo- and copolymers. 
Table 2. Results of polymerizations.

\begin{tabular}{|c|c|c|c|c|}
\hline Code & Yield (\%) & $M_{\mathrm{n}}{ }^{1} \times 10^{-3}$ & $M w^{1} \times 10^{-3}$ & $M_{\mathrm{w}} / M_{\mathrm{n}}$ \\
\hline P-MAImC 1 -PW 12 & 85 & $7.47^{(\mathrm{a})}$ & $7.96^{\text {(a) }}$ & $1.07^{\text {(a) }}$ \\
\hline CP-MAImC ${ }_{1}-\mathrm{PW}_{12} / \mathrm{BMA}_{(1: 1)}$ & 67 & $35.4^{(\mathrm{a})}$ & $45.4^{(\mathrm{a})}$ & $1.28^{\text {(a) }}$ \\
\hline CP-MAImC ${ }_{1}-\mathrm{PW}_{12} / \mathrm{BMA}(1: 3)$ & 68 & $9.88^{(b)}$ & $12.1^{(b)}$ & $1.17^{(b)}$ \\
\hline PBMA homopolymer & 71 & $20.1^{(b)}$ & $28.8^{(b)}$ & $1.44^{(b)}$ \\
\hline
\end{tabular}

${ }^{1}$ Number- and weight-average molecular weights $\left(M_{\mathrm{n}}\right.$ and $\left.M_{\mathrm{w}}\right)$ were determined by GPC using ${ }^{\text {(a) }} 20 \mathrm{mM} \mathrm{LiBr}$ solution in DMF or ${ }^{(b)}$ THF as an eluent.

IR spectroscopy confirmed successful polymerization of the MAImC ${ }_{1}-\mathrm{PW}_{12}$ hybrid monomer. IR spectra of MAImC ${ }_{1}-\mathrm{PW}_{12}$ hybrid homopolymer (Figure $4 \mathrm{~b}$ ) and copolymers (Figure $4 \mathrm{c}, \mathrm{d}$ ) exhibited characteristic peaks of the $\mathrm{PW}_{12}$ anion in the range of $400-1100 \mathrm{~cm}^{-1}$ as observed for that of the $\mathrm{MAImC}_{1}-\mathrm{PW}_{12}$ hybrid monomer (Figure 4a).

The thermal stability of these hybrid polymers was evaluated by thermogravimetric analysis (TGA), and compared with poly(butyl methacrylate) (PBMA) as shown in Figure 5. It was found from the TGA curves that the thermal degradation of the hybrid homo- and copolymers of $\mathrm{MAImC}_{1}-\mathrm{PW}_{12}$ mainly occurred at around 503-553 K, whereas that of PBMA occurred at just over $473 \mathrm{~K}$. Probably, the thermal degradation of the hybrid polymers would be induced by a decomposition of the organic components, imidazolium groups, at ca. $500 \mathrm{~K}$, whereas the starting temperatures of degradation for all the hybrid polymers were higher than that of purely-organic PBMA polymer. Notably, $\mathrm{CP}-\mathrm{MAImC} \mathrm{C}_{1}-\mathrm{PW}_{12} / \mathrm{MAImC}_{8} \mathrm{Br}$ hybrid copolymer exhibiting moderate conductivity (see below) was much more stable than PBMA. It was considered that the weight loss of these hybrid polymers would be derived from the degradation of the polymer side chain. These results indicated that the hybridization with the $\mathrm{PW}_{12}$ inorganic anions enhanced the thermal stability of the organic polymers.

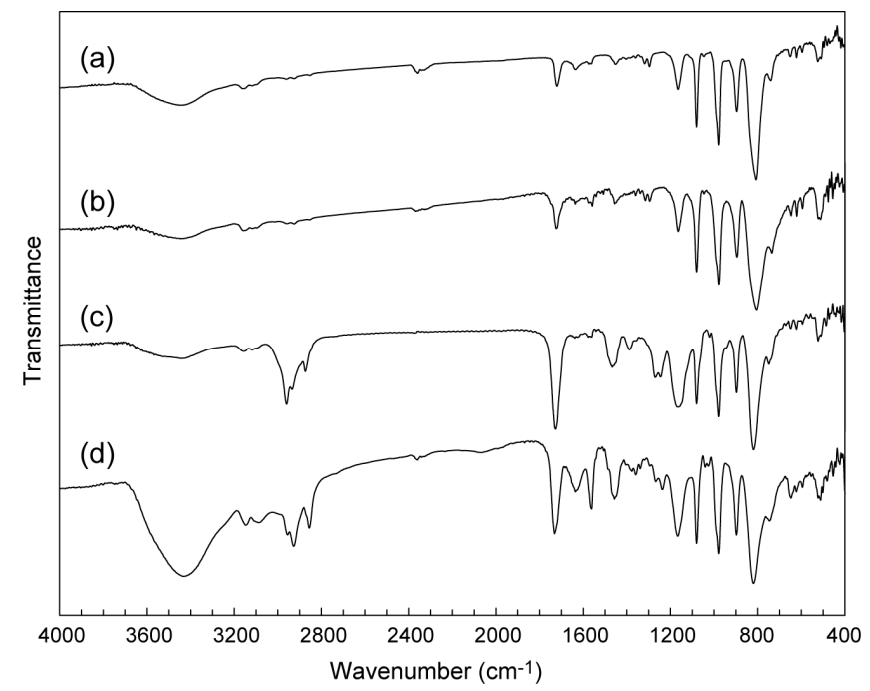

Figure 4. IR spectra of $\mathrm{MAImC}_{1}-\mathrm{PW}_{12}$ hybrids: (a) $\mathrm{MAImC}_{1}-\mathrm{PW}_{12}$ hybrid monomer; (b) P-MAImC $\mathrm{C}_{1}-\mathrm{PW}_{12}$ hybrid homopolymer by using DMF; (c) CP-MAImC 1 - $\mathrm{PW}_{12} / \mathrm{BMA}$ hybrid copolymer; and (d) CP-MAImC ${ }_{1}-\mathrm{PW}_{12} / \mathrm{MAImC}_{8} \mathrm{Br}$ hybrid copolymer.

Figure 6 shows powder XRD patterns of the MAImC $\mathrm{C}_{1}-\mathrm{PW}_{12}$ hybrid homo- and copolymers. As shown in Figure 6a, MAImC 1 - $\mathrm{PW}_{12}$ hybrid homopolymer prepared with DMSO exhibited an XRD pattern similar to that of crystalline MAImC $\mathrm{C}_{1}-\mathrm{PW}_{12}$ hybrid monomer (Figure $2 \mathrm{~b}$ ). This indicates that the polymerization did not proceed sufficiently, being consistent with the molecular weight estimated by GPC (Table 2). On the contrary, the XRD pattern of the MAImC ${ }_{1}-\mathrm{PW}_{12}$ hybrid homopolymer prepared with DMF (Figure 6b) did not show any peak except for halo patterns typical for amorphous 
polymer phase, suggesting that the $\mathrm{MAImC}_{1}-\mathrm{PW}_{12}$ hybrid monomer was successfully polymerized. Both XRD patterns of MAImC $1-\mathrm{PW}_{12}$ hybrid copolymers (Figure $6 c, \mathrm{~d}$ ) showed halo peaks typical for an amorphous polymer phase, supported by the GPC results (Table 2).

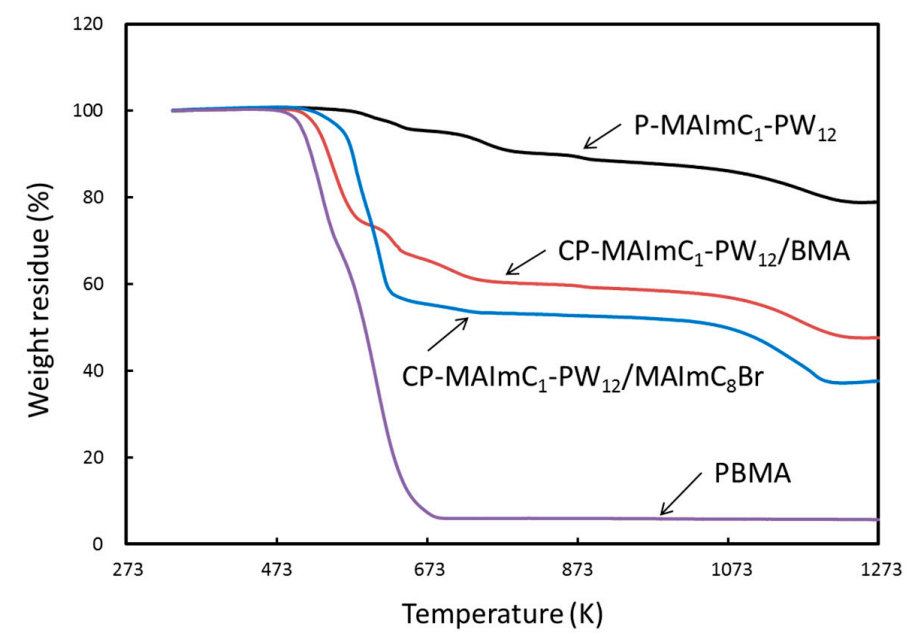

Figure 5. Thermogravimetric curves of $\mathrm{MAImC}_{1}-\mathrm{PW}_{12}$ hybrid homo- and copolymers as compared with poly(butyl methacrylate) (PBMA).

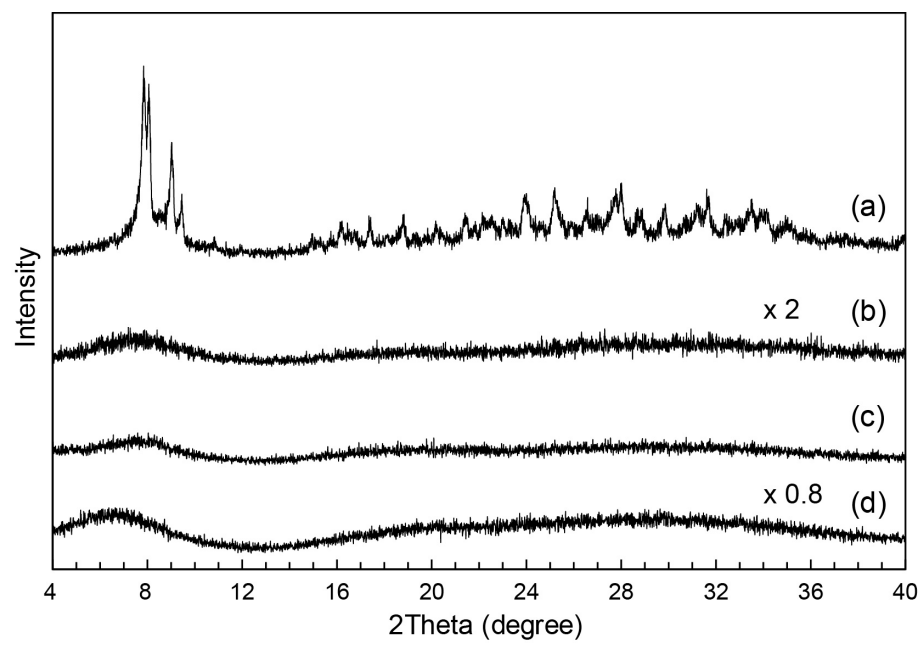

Figure 6. Powder X-ray diffraction patterns of $\mathrm{MAImC}_{1}-\mathrm{PW}_{12}$ hybrids: (a) P-MAImC $\mathrm{I}_{1}-\mathrm{PW}_{12}$ hybrid homopolymer prepared by using DMSO; (b) P-MAImC $\mathrm{C}_{1}-\mathrm{PW}_{12}$ hybrid homopolymer prepared by using DMF; (c) CP-MAImC 1 - $\mathrm{PW}_{12} / \mathrm{BMA}$ hybrid copolymer; and (d) CP-MAImC $-\mathrm{PW}_{12} / \mathrm{MAImC}_{8} \mathrm{Br}$ hybrid copolymer.

\subsection{Conductivity of $M A I m C_{1}-P W_{12}$ Hybrid Monomer and Polymers}

Table 3 shows conductivity values of $\mathrm{MAImC}_{1}-\mathrm{PW}_{12}$ hybrid monomer and polymers measured under less- or fully-humidified conditions. Most samples, unfortunately, exhibited rather low conductivity below the order of $10^{-7} \mathrm{~S} \cdot \mathrm{cm}^{-1}$ despite the degree of polymerization and/or presence of humidity. However, the copolymer of $\mathrm{MAImC}_{1}-\mathrm{PW}_{12}$ with $\mathrm{MAImC}_{8}-\mathrm{Br}$ (CP-MAImC 1 - $\mathrm{PW}_{12} / \mathrm{MAImC}_{8} \mathrm{Br}$ (1:1)) exhibited much better conductivity. The Nyquist plots (Figure 7) changed drastically with or without additional humidification, and the conductivities were estimated by the resistance $\left(R_{1}\right)$ simulated by the equivalent circuits depicted in Figure 7 . Table 4 shows estimated parameters with these equivalent circuits. The conductivity under relative humidity (denoted as RH) of $95 \%$ was $5.7 \times 10^{-4} \mathrm{~S} \cdot \mathrm{cm}^{-1}$, which was a moderate value at the lower temperature 
(313 K). The conductivity of the CP-MAImC $1-\mathrm{PW}_{12} / \mathrm{MAImC}_{8} \mathrm{Br}$ hybrid copolymer depended on the ratio of $\mathrm{MAImC}_{1}-\mathrm{PW}_{12}$ hybrid monomer and $\mathrm{MAImC}_{8}-\mathrm{Br}$ comonomer. The higher the ratio of $\mathrm{MAImC}_{1}-\mathrm{PW}_{12}$ hybrid monomer to $\mathrm{MAImC}_{8}-\mathrm{Br}$ comonomer, the lower the conductivity was: the conductivity of CP-MAImC 1 - $\mathrm{PW}_{12} / \mathrm{MAImC}_{8} \mathrm{Br}(3: 1)$ with additional humidity $\left(3.5 \times 10^{-6} \mathrm{~S} \cdot \mathrm{cm}^{-1}\right)$ was two orders of magnitude lower than that of CP-MAImC ${ }_{1}-\mathrm{PW}_{12} / \mathrm{MAImC}_{8} \mathrm{Br}$ (1:1) (Table 3). Therefore, the moderate conductivity of $\mathrm{CP}-\mathrm{MAImC}_{1}-\mathrm{PW}_{12} / \mathrm{MAImC}_{8} \mathrm{Br}$ under humidified conditions was derived from polymerized $\mathrm{MAImC}_{8}-\mathrm{Br}$ moiety, which was confirmed by high conductivity $\left(3.2 \times 10^{-3} \mathrm{~S} \cdot \mathrm{cm}^{-1}\right)$ of homopolymer of $\mathrm{MAImC}_{8}-\mathrm{Br}\left(\mathrm{P}-\mathrm{MAImC} \mathrm{C}_{8} \mathrm{Br}\right)$ as shown in Table 3. However, $\mathrm{P}$-MAImC ${ }_{8} \mathrm{Br}$ irreversibly expanded under humidified conditions to result in a gel-like material, and the durability of P-MAImC ${ }_{8} \mathrm{Br}$ against humidity was quite low, and the conductivity measurement was able only one time. On the other hand, CP-MAImC ${ }_{1}-\mathrm{PW}_{12} / \mathrm{MAImC}_{8} \mathrm{Br}$ hybrid copolymers endured the presence of humidity, and the conductivity measurements were carried out repeatedly. Therefore, the hybridization of $\mathrm{MAImC}_{1}-\mathrm{PW}_{12}$ with $\mathrm{MAImC}_{8} \mathrm{Br}$ seems crucial for the increase in durability of $\mathrm{P}$-MAImC $\mathrm{C}_{8} \mathrm{Br}$ homopolymer and the emergence of moderate conductivity.

Table 3. Conductivity values of $\mathrm{MAImC}_{1}-\mathrm{PW}_{12}$ hybrids with or without additional humidity.

\begin{tabular}{|c|c|c|c|}
\hline Code & $\begin{array}{l}\text { Without Additional } \\
\text { Humidity (Measured } \\
\text { at } 298 \mathrm{~K})\left(\mathrm{S} \cdot \mathrm{cm}^{-1}\right)\end{array}$ & $\begin{array}{l}\text { Without Additional } \\
\text { Humidity (Measured } \\
\text { Temperature) }\left(\mathrm{S} \cdot \mathrm{cm}^{-1}\right)\end{array}$ & $\begin{array}{c}\text { With Additional Humidity of } \\
\text { 95\% RH (Measured } \\
\text { Temperature) }\left(\mathrm{S} \cdot \mathrm{cm}^{-1}\right)\end{array}$ \\
\hline MAImC $_{1}-\mathrm{PW}_{12}$ & $1.2 \times 10^{-8}$ & $3.0 \times 10^{-8}(327 \mathrm{~K})$ & $3.0 \times 10^{-7}(327 \mathrm{~K})$ \\
\hline $\mathrm{P}^{-M A I m C}{ }_{1}-\mathrm{PW}_{12}$ & $8.4 \times 10^{-10}$ & $2.0 \times 10^{-7}(373 \mathrm{~K})$ & $7.4 \times 10^{-6}(373 \mathrm{~K})$ \\
\hline $\begin{array}{c}\text { CP-MAImC } 1^{-} \\
\text {PW }_{12} / \text { BMA }^{-1: 3)}\end{array}$ & $8.6 \times 10^{-10}$ & $5.2 \times 10^{-8}(373 \mathrm{~K})$ & $1.5 \times 10^{-9}(373 \mathrm{~K})$ \\
\hline $\begin{array}{c}\text { CP-MAImC } 1^{-} \\
\mathrm{PW}_{12} / \mathrm{MAImC}_{8} \mathrm{Br}(1: 1)\end{array}$ & $3.3 \times 10^{-7}$ & $8.4 \times 10^{-7}(313 \mathrm{~K})$ & $5.7 \times 10^{-4}(313 \mathrm{~K})$ \\
\hline $\begin{array}{c}\text { CP-MAImC } 1^{-} \\
\mathrm{PW}_{12} / \mathrm{MAImC}_{8} \mathrm{Br}(3: 1)\end{array}$ & $6.0 \times 10^{-8}$ & $7.2 \times 10^{-8}(313 \mathrm{~K})$ & $3.5 \times 10^{-6}(313 \mathrm{~K})$ \\
\hline P-MAImC ${ }_{8} \mathrm{Br}$ & $1.8 \times 10^{-6}$ & $9.2 \times 10^{-6}(313 \mathrm{~K})$ & $3.2 \times 10^{-3}(313 \mathrm{~K})^{1}$ \\
\hline
\end{tabular}

${ }^{1}$ The durability of the sample against humidity was very low.
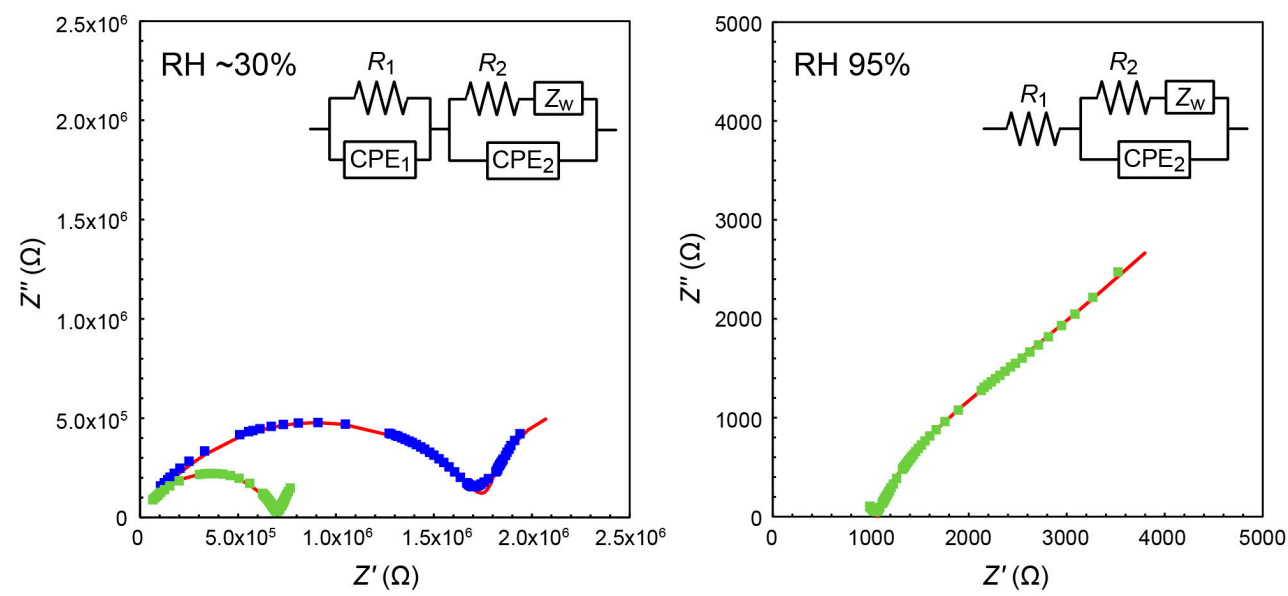

Figure 7. Nyquist plots of CP-MAImC ${ }_{1}-\mathrm{PW}_{12} / \mathrm{MAImC}_{8} \mathrm{Br}$ (1:1) hybrid copolymer at $298 \mathrm{~K}$ (blue) and $313 \mathrm{~K}$ (green) without additional humidity ( $\mathrm{RH} \sim 30 \%$ ) (left) and with additional humidity of $\mathrm{RH} 95 \%$ (right). The simulated spectra (red line) are based on an equivalent electronic circuit in the figure. 
Table 4. Estimated parameters with the equivalent circuit for $\mathrm{CP}-\mathrm{MAImC} \mathrm{I}_{1}-\mathrm{PW}_{12} / \mathrm{MAImC}_{8} \mathrm{Br}(1: 1)$.

\begin{tabular}{cccc}
\hline $\begin{array}{c}\text { Circuit } \\
\text { Parameter }\end{array}$ & $\begin{array}{c}\text { Without Additional } \\
\text { Humidity at 298 K }\end{array}$ & $\begin{array}{c}\text { Without Additional } \\
\text { Humidity at } \mathbf{3 1 3} \mathbf{~ K}\end{array}$ & $\begin{array}{c}\text { With Additional Humidity of } \\
\mathbf{9 5 \%} \mathbf{~ R H} \text { at 313 K }\end{array}$ \\
\hline$R_{1}(\Omega)$ & $1.78 \times 10^{6}$ & $7.06 \times 10^{5}$ & $1.09 \times 10^{3}$ \\
$\mathrm{CPE}_{1}-P^{1}$ & $2.70 \times 10^{-10}$ & $1.23 \times 10^{-10}$ & - \\
$\mathrm{CPE}_{1}-n$ & 0.627 & 0.714 & - \\
$R_{2}(\Omega)$ & $2.77 \times 10^{7}$ & $4.98 \times 10^{9}$ & $2.98 \times 10^{3}$ \\
$\mathrm{CPE}_{2}-P^{1}$ & $4.79 \times 10^{-8}$ & $1.51 \times 10^{-7}$ & $3.26 \times 10^{-6}$ \\
$\mathrm{CPE}_{2}-n$ & 0.757 & 0.759 & 0.76 \\
$\sigma^{2}$ & $2.90 \times 10^{4}$ & $2.90 \times 10^{4}$ & $2.90 \times 10^{4}$ \\
\hline 1 Constant phase element $(\mathrm{CPE})$ defined as $Z(\omega)=P^{-1}(j \cdot \omega)^{-n} . P$ in $\Omega^{-1} \mathrm{~s}^{-n}, n$ in non-dimensional. ${ }^{2}$ Warburg \\
impedance defined as $Z_{\mathrm{w}}=(1-j) \sigma(\omega)^{-1 / 2} . \sigma$ in $\Omega \mathrm{s}^{-1 / 2}$.
\end{tabular}

\section{Discussion}

The newly-designed polymerizable ionic liquid cation of MAImC $\mathrm{I}_{1}$ was successfully hybridized with heteropolyanion of dodecatungstophosphate $\left(\mathrm{PW}_{12}\right)$. The inorganic-organic hybrid momomer of MAImC $1-\mathrm{PW}_{12}$ was revealed to be polymerized by a radical polymerization using AIBN as an initiator. Both hybrid monomer and polymers contained imidazolium moieties, and were expected to work as ionic or proton conductors [10-13,23].

These MAImC $\mathrm{C}_{1}-\mathrm{PW}_{12}$ hybrid monomer and polymers have an advantage to the generality on the selection of polyoxometalate anions and ionic liquid cations. In our compounds, the polymerizable ionic liquid moiety is a cationic species and interacts with heteropolyanions to form ionic hybrid monomer compounds $[37,38]$. In principle, the organic ionic liquid moiety can be flexibly designed in terms of organic syntheses, and the inorganic polyoxometalate anions can be variously selected, indicating more versatility than other polyoxometalate-polymer systems using polyoxometalate with the organic moiety grafted by covalent bonding [25-36]. Additionally, the MAImC $\mathrm{C}_{1}-\mathrm{PW}_{12}$ hybrid monomer can be obtained as single crystals [28-32], which enabled unambiguous characterization of the key starting material. Other combinations of the polymerizable ionic liquid moiety and polyoxometalate are now investigated.

The carrier for the conduction of CP-MAImC $1-\mathrm{PW}_{12} / \mathrm{MAImC}_{8} \mathrm{Br}$ is unclear. The conductivity increased under the presence of water vapor, indicating the water molecules may assist the moving of carriers. The proton conductivity often increases under the presence of water vapor [3]. Therefore, the carrier in CP-MAImC $C_{1}-\mathrm{PW}_{12} / \mathrm{MAImC}_{8} \mathrm{Br}$ is suggested to be proton. The proton may be derived from water molecules, since the MAImC $\mathrm{CWW}_{12}$ hybrid monomer and polymers have no residual protons, as revealed by single-crystal structure analysis. As mentioned above, the moderate conductivity of CP-MAImC 1 - $\mathrm{PW}_{12} / \mathrm{MAImC}_{8} \mathrm{Br}(1: 1)\left(5.7 \times 10^{-4} \mathrm{~S} \cdot \mathrm{cm}^{-1}\right.$ at $\left.313 \mathrm{~K}\right)$ was derived from the MAImC ${ }_{8}$-Br moiety (Table 3). The water molecules may loosen the polymer chain of the polymerized $\mathrm{MAImC}_{8}$ - $\mathrm{Br}$ moiety, and the carrier species could move more easily under the presence of humidity. The CP-MAImC ${ }_{1}-\mathrm{PW}_{12} / \mathrm{MAImC}_{8} \mathrm{Br}$ hybrid copolymer had good durability against water vapor, while the purely organic $\mathrm{P}-\mathrm{MAImC} \mathrm{C}_{8} \mathrm{Br}$ polymer was quite sensitive against humidity. The increase in the durability against humidity will be derived from the introduction of $\mathrm{PW}_{12}$ anions into P-MAImC ${ }_{8} \mathrm{Br}$, and the hybridization with the inorganic moiety has been revealed to be effective for possible inorganic-organic hybrid solid electrolyte [49].

\section{Conclusions}

Polymerizable ionic liquid (MAImC ${ }_{1}$ ) was utilized to construct the inorganic-organic hybrid monomer with heteropolyanions $\left(\mathrm{PW}_{12}\right)$. The hybrid monomer was synthesized by a cation exchange reaction, and obtained as single crystals. This new hybrid monomer was successfully polymerized by a radical polymerization to form several types of homo- and copolymers. Copolymerization of $\mathrm{MAImC}_{1}-\mathrm{PW}_{12}$ with $\mathrm{MAImC}_{8}-\mathrm{Br}$ resulted in the formation of a possible solid 
electrolyte. The conductivity of the inorganic-organic hybrid copolymer had a moderate value of $5.7 \times 10^{-4} \mathrm{~S} \cdot \mathrm{cm}^{-1}$ at $313 \mathrm{~K}$ under humidified conditions.

Supplementary Materials: Supplementary materials are available online at www.mdpi.com/2073-4360/9/7/ $290 /$ s1.

Acknowledgments: This work was financially supported, in part, by JSPS KAKENHI, grant number JP26410245, and the Research and Study Project of Tokai University Educational System General Research Organization. X-ray diffraction measurements with synchrotron radiation were performed at the Pohang Accelerator Laboratory (Beamline 2D) supported by POSTECH.

Author Contributions: Takeru Ito, Shinichi Koguchi, Masashi Higuchi, and Yu Nagase conceived and designed the experiments; Shinichi Koguchi performed the synthesis of MAImC 1 -I; Saki Otobe, Yoshiki Kiyota, and Toshiyuki Misawa performed the synthesis and characterization of the MAImC $1-\mathrm{PW}_{12}$ hybrid monomer; Saki Otobe, Tatsuhiro Kojima, and Masaki Kawano carried out the diffraction measurements with synchrotron radiation; Tatsuhiro Kojima, Saki Otobe, and Takeru Ito analyzed the diffraction data; Tatsuma Oda and Masayuki Watanabe performed the synthesis and characterization of $\mathrm{MAImC}_{1}-\mathrm{PW}_{12}$ hybrid polymers; Seiji Ono performed conductivity measurements and analyzed the data; and Takeru Ito, Shinichi Koguchi, Masashi Higuchi, and Yu Nagase discussed on the results and wrote the paper.

Conflicts of Interest: The authors declare no conflict of interest.

\section{References}

1. Whittingham, M.S. Lithium batteries and cathode materials. Chem. Rev. 2004, 104, 4271-4301. [CrossRef] [PubMed]

2. Goodenough, J.B.; Park, K.-S. The Li-ion rechargeable battery: A perspective. J. Am. Chem. Soc. 2013, 135, 1167-1176. [CrossRef] [PubMed]

3. Steele, B.C.H.; Heinzel, A. Materials for fuel-cell technologies. Nature 2001, 414, 345-352. [CrossRef] [PubMed]

4. Yoon, M.; Suh, K.; Natarajan, S.; Kim, K. Proton conduction in metal-organic frameworks and related modularly built porous solids. Angew. Chem. Int. Ed. 2013, 52, 2688-2700. [CrossRef] [PubMed]

5. Coronado, E.; Gómez-García, C.J. Polyoxometalate-based molecular materials. Chem. Rev. 1998, 98, 273-296. [CrossRef] [PubMed]

6. Coronado, E.; Giménez-Saiz, C.; Gómez-García, C.J. Recent advances in polyoxometalate-containing molecular conductors. Coord. Chem. Rev. 2005, 249, 1776-1796. [CrossRef]

7. Welton, T. Room-temperature ionic liquids. Solvents for synthesis and catalysis. Chem. Rev. 1999, 99, 2071-2083. [CrossRef] [PubMed]

8. Wasserscheid, P.; Keim, W. Ionic liquids-new "solutions" for transition maetal catalysis. Angew. Chem. Int. Ed. 2000, 39, 3772-3789. [CrossRef]

9. Haumann, M.; Riisager, A. Hydroformylation in room temperature ionic liquids (RTILs): Catalyst and process developments. Chem. Rev. 2008, 108, 1474-1497. [CrossRef] [PubMed]

10. Kato, T.; Mizoshita, N.; Kishimoto, K. Functional liquid-crystalline assemblies: Self-organized soft materials. Angew. Chem. Int. Ed. 2006, 45, 38-68. [CrossRef] [PubMed]

11. Nishimura, N.; Ohno, H. 15th anniversary of polymerised ionic liquids. Polymer 2014, 55, 3289-3297. [CrossRef]

12. Bureekaew, S.; Horike, S.; Higuchi, M.; Mizuno, M.; Kawamura, T.; Tanaka, D.; Yanai, N.; Kitagawa, S. One-dimensional imidazole aggregate in aluminium porous coordination polymers with high proton conductivity. Nat. Mater. 2009, 8, 831-836. [CrossRef] [PubMed]

13. Watanabe, M.; Thomas, M.L.; Zhang, S.; Ueno, K.; Yasuda, T.; Dokko, K. Application of ionic liquids to energy storage and conversion materials and devices. Chem. Rev. 2017, 117, 7190-7239. [CrossRef] [PubMed]

14. Long, D.-L.; Burkholder, E.; Cronin, L. Polyoxometalate clusters, nanostructures and materials: From self assembly to designer materials and devices. Chem. Soc. Rev. 2007, 36, 105-121. [CrossRef] [PubMed]

15. Nyman, M. Polyoxoniobate chemistry in the 21st century. Dalton Trans. 2011, 40, 8049-8058. [CrossRef] [PubMed]

16. Proust, A.; Matt, B.; Villanneau, R.; Guillemot, G.; Gouzerh, P.; Izzet, G. Functionalization and post-functionalization: A step towards polyoxometalate-based materials. Chem. Soc. Rev. 2012, 41, 7605-7622. [CrossRef] [PubMed] 
17. Okuhara, T.; Mizuno, N.; Misono, M. Catalytic chemistry of heteropoly compounds. Adv. Catal. 1996, 41, 113-252.

18. Yamase, T. Photo- and electrochromism of polyoxometalates and related materials. Chem. Rev. 1998, 98, 307-325. [CrossRef] [PubMed]

19. Sadakane, M.; Steckhan, E. Electrochemical properties of polyoxometalates as electrocatalysts. Chem. Rev. 1998, 98, 219-237. [CrossRef] [PubMed]

20. Nakamura, O.; Kodama, T.; Ogino, I.; Miyake, Y. High-conductivity solid proton conductors: Dodecamolybdophosphoric acid and dodecatungstophosphoric acid crystals. Chem. Lett. 1979, 8, 17-18. [CrossRef]

21. Bourlinos, A.B.; Raman, K.; Herrera, R.; Zhang, Q.; Archer, L.A.; Giannelis, E.P. A liquid derivative of 12-tungstophosphoric acid with unusually high conductivity. J. Am. Chem. Soc. 2004, 126, 15358-15359. [CrossRef] [PubMed]

22. Wu, X.; Tong, X.; Wu, Q.; Ding, H.; Yan, W. Reversible phase transformation-type electrolyte based on layered shape polyoxometalate. J. Mater. Chem. A 2014, 2, 5780-5784. [CrossRef]

23. Honma, I.; Yamada, M. Bio-inspired membranes for advanced polymer electrolyte fuel cells. Anhydrous proton-conducting membrane via molecular self-assembly. Bull. Chem. Soc. Jpn. 2007, 80, 2110-2123. [CrossRef]

24. Oh, S.-Y.; Yoshida, T.; Kawamura, G.; Muto, H.; Sakai, M.; Matsuda, A. Inorganic-organic composite electrolytes consisting of polybenzimidazole and Cs-substituted heteropoly acids and their application for medium temperature fuel cells. J. Mater. Chem. 2010, 20, 6359-6366. [CrossRef]

25. Judeinstein, P. Synthesis and properties of polyoxometalates based inorganic-organic polymers. Chem. Mater. 1992, 4, 4-7. [CrossRef]

26. Mayer, C.R.; Thouvenot, R.; Lalot, T. New hybrid covalent networks based on polyoxometalates: Part 1. Hybrid networks based on poly(ethyl methacrylate) chains covalently cross-linked by heteropolyanions: Synthesis and swelling properties. Chem. Mater. 2000, 12, 257-260. [CrossRef]

27. Mayer, C.R.; Thouvenot, R.; Lalot, T. Hybrid hydrogels obtained by the copolymerization of acrylamide with aggregates of methacryloyl derivatives of polyoxotungstates. A comparison with polyacrylamide hydrogels with trapped aggregates. Macromolecules 2000, 33, 4433-4437. [CrossRef]

28. Moore, A.R.; Kwen, H.; Beatty, A.M.; Eric, A.; Maatta, E.A. Organoimido-polyoxometalates as polymer pendants. Chem. Commun. 2000, 1793-1794. [CrossRef]

29. Lu, M.; Xie, B.; Kang, J.; Chen, F.-C.; Yang, Y.; Peng, Z. Synthesis of main-chain polyoxometalate-containing hybrid polymers and their applications in photovoltaic cells. Chem. Mater. 2005, 17, 402-408. [CrossRef]

30. Xu, B.; Lu, M.; Kang, J.; Wang, D.; Brown, J.; Peng, Z. Synthesis and optical properties of conjugated polymers containing polyoxometalate clusters as side-chain pendants. Chem. Mater. 2005, 17, 2841-2851. [CrossRef]

31. Hasegawa, T.; Shimizu, K.; Seki, H.; Murakami, H.; Yoshida, S.; Yoza, K.; Nomiya, K. Polymerizable inorganic-organic hybrid: Syntheses and structures of mono-lacunary Dawson polyoxometalate-based olefin-containing organosilyl derivatives. Inorg. Chem. Commun. 2007, 10, 1140-1144. [CrossRef]

32. Hasegawa, T.; Murakami, H.; Shimizu, K.; Kasahara, Y.; Yoshida, S.; Kurashina, T.; Seki, H.; Nomiya, K. Formation of inorganic protonic-acid polymer via inorganic-organic hybridization: Synthesis and characterization of polymerizable olefinic organosilyl derivatives of mono-lacunary Dawson polyoxometalate. Inorg. Chim. Acta 2008, 361, 1385-1394. [CrossRef]

33. Horan, J.L.; Genupur, A.; Ren, H.; Sikora, B.J.; Kuo, M.-C.; Meng, F.; Dec, S.F.; Haugen, G.M.; Yandrasits, M.A.; Hamrock, S.J.; et al. Copolymerization of divinylsilyl-11-silicotungstic acid with butyl acrylate and hexanediol diacrylate: Synthesis of a highly proton-conductive membrane for fuel-cell applications. ChemSusChem 2009, 2, 226-229. [CrossRef] [PubMed]

34. Han, Y.; Xiao, Y.; Zhang, Z.; Liu, B.; Zheng, P.; He, S.; Wang, W. Synthesis of polyoxometalate-polymer hybrid polymers and their hybrid vesicular assembly. Macromolecules 2009, 42, 6543-6548. [CrossRef]

35. Miao, W.-K.; Yan, Y.-K.; Wang, X.-L.; Xiao, Y.; Ren, L.-J.; Zheng, P.; Wang, C.-H.; Ren, L.-X.; Wang, W. Incorporation of polyoxometalates into polymers to create linear poly(polyoxometalate)s with catalytic function. ACS Macro Lett. 2014, 3, 211-215. [CrossRef]

36. Macdonell, A.; Johnson, N.A.B.; Surman, A.J.; Cronin, L. Configurable nanosized metal oxide oligomers via precise "click" coupling control of hybrid polyoxometalates. J. Am. Chem. Soc. 2015, 137, 5662-5665. [CrossRef] [PubMed] 
37. Li, H.; Qi, W.; Li, W.; Sun, H.; Bu, W.; Wu, L. A highly transparent and luminescent hybrid based on the copolymerization of surfactant-encapsulated polyoxometalate and methyl methacrylate. Adv. Mater. 2005, 17, 2688-2692. [CrossRef]

38. Qi, W.; Wu, L. Polyoxometalate/polymer hybrid materials: Fabrication and properties. Polym. Int. 2009, 58, 1217-1225. [CrossRef]

39. Otwinowski, Z.; Minor, W. Processing of X-ray diffraction data collected in oscillation mode. Methods Enzymol. 1997, 276, 307-326. [PubMed]

40. Spek, A.L. Structure validation in chemical crystallography. Acta Crystallogr. Sect. D 2009, 65, 148-155. [CrossRef] [PubMed]

41. Sheldrick, G.M. SHELXT-Integrated space-group and crystal structure determination. Acta Crystallogr. Sect. A 2015, 71, 3-8. [CrossRef] [PubMed]

42. Sheldrick, G.M. A short history of SHELX. Acta Crystallogr. Sect. A 2008, 64, 112-122. [CrossRef] [PubMed]

43. Ito, T.; Ide, R.; Kosaka, K.; Hasegawa, S.; Mikurube, K.; Taira, M.; Naruke, H.; Koguchi, S. Polyoxomolybdate-surfactant layered crystals derived from long-tailed alkylamine and ionic-liquid. Chem. Lett. 2013, 42, 1400-1402. [CrossRef]

44. Ito, T.; Mikurube, K.; Hasegawa, K.; Matsumoto, T.; Kosaka, K.; Naruke, H.; Koguchi, S. Structural variation in polyoxomolybdate hybrid crystals comprising ionic-liquid surfactants. Crystals 2014, 4, 42-52. [CrossRef]

45. Kobayashi, J.; Kawahara, R.; Uchida, S.; Koguchi, S.; Ito, T. Conductive hybrid crystal composed from polyoxomolybdate and deprotonatable ionic-liquid surfactant. Int. J. Mol. Sci. 2016, 17, 994. [CrossRef] [PubMed]

46. Rocchiccioli-Deltcheff, C.; Fournier, M.; Franck, R.; Thouvenot, R. Vibrational investigations of polyoxometalates. 2. Evidence for anion-anion interactions in molybdenum(v1) and tungsten(v1) compounds related to the Keggin structure. Inorg. Chem. 1983, 22, 207-216. [CrossRef]

47. Evans, H.T., Jr.; Pope, M.T. Reinterpretation of five recent crystal structures of heteropoly and isopoly complexes: Divanadodecamolybdopbosphate, trivanadoenneamolybdopbospbate, " $\gamma$-dodecatungstophospbate", the dodecamolybdate-dodecamolybdomolybdate blue complex, and dihydrogen decavanadate. Inorg. Chem. 1984, 23, 501-504.

48. Dong, J.; Hu, J.; Chi, Y.; Lin, Z.; Zou, B.; Yang, S.; Hill, C.L.; Hu, C. A polyoxoniobate-polyoxovanadate double-anion catalyst for simultaneous oxidative and hydrolytic decontamination of chemical warfare agent simulants. Angew. Chem. Int. Ed. 2017, 56, 4473-4477. [CrossRef] [PubMed]

49. Herrmann, S.; Ritchie, C.; Streb, C. Polyoxometalate-Conductive polymer composites for energy conversion, energy storage and nanostructured sensors. Dalton Trans. 2015, 44, 7092-7104. [CrossRef] [PubMed] 